\title{
AKTIVITAS FISIK, ASUPAN ENERGI, DAN PRODUKTIVITAS KERJA PRIA DEWASA: STUDI KASUS DI PERKEBUNAN TEH MALABAR PTPN VIII BANDUNG, JAWA BARAT
}

(Physical Activity, Energy Intake, and Productivity Men Workers:

Case Study at Tea Plantation PTPN VIII Bandung, West J ava)

Noni Eka Jaya Wardani ${ }^{1}$ dan Katrin Roosita ${ }^{2 *}$

1 Program Studi Gizi Masyarakat dan Sumberdaya Keluarga, Fakultas Pertanian (FAPERTA) IPB.
2 Departemen Gizi Masyarakat, Fakultas Ekologi Manusia (FEMA), IPB
Tel: 0251-8628304/8621258; Fax: 0251-8625846/8622276

\begin{abstract}
ABST RACT
The cross sectional design was used in this study to elaborate physical activity, energy consumption, and work productivity of men workers. The total number of sample is 72 men. The inclusion criteria of the sample is the head of household's women tea pickers at Tea Plantation PTPN VIII Bandung, West J ava who have children 0-72 month age and willing to be interviewed. The place of the research was chose purposively. Malabar Plantation was chosen from the other five plantations (clusters) cause of its easier access and the homogenous characteristics inter cluster. Data collected was analyzed statistically. In general, more than a half of samples had active or moderately physical activity level ( $P A L=1.89)$. The physical activity level of samples during work day (average $P A L=1.93)$ was higher than holiday (average $P A L=1.77)(p \varangle 0.05)$. The working hours during holiday were substituted by doing domestic chores and miscellaneous recreational activities. There are significant differences $(p<0.05)$ of energy requirement based on three calculation (Schofield equation, Oxford equation, and energy RDI on WNPG (2004)). Average energy consumption of men workers were 87.2 - 121.2\% Majority of samples (76.4\%) had wages per month below the regional minimum wages. The working hours of more than a half of samples were below seven hours per day and had wages per hour below standard regional minimum wage. Based on correlation analysis, there are significant correlation between 1) education level with physical activity level; 2) age, income per capita, and family size with wage per month; 3 ) age and physical activity level with working hours; and 4) age and income per capita with wages per hour.
\end{abstract}

Keywords: physical activity, energy expenditure, energy adequacy level, work productivity, tea picker's household head.

\section{PENDAHULUAN}

Keluarga memerlukan sumberdaya termasuk uang agar dapat memenuhi kebutuhan tiap individu dalam keluarga. Komunitas wanita pemetik teh telah menjadi sorotan selama beberapa tahun belakangan. Wanita pemetik teh bekerja mencari nafkah bagi kehidupan keluarga. Namun mencari nafkah pada dasarnya merupakan kewajiban seorang suami. Istiadah (1999) menyatakan bahwa suami merupakan kepala rumahtangga sekaligus pencari nafkah utama bagi kehidupan keluarga. Pendapatan keluarga yang paling utama biasanya didapatkan dari suami atau ayah. Pendapatan atau upah didapatkan dari hasil melakukan

* Penulis untuk korespondensi, Departemen Gizi Masyarakat, FEMA, IPB; Tel: 0251-8628304/8621258: Fax: 0251-8625846/8622276

Email: kroosita@yahoo.com suatu pekerjaan. Seseorang yang bekerja dengan lebih produktif memiliki kemungkinan untuk mendapatkan upah yang lebih besar dibanding seseorang yang kurang produktif Ravianto (1990).

Produktivitas merupakan salah satu cerminan kualitas sumberdaya manusia (Syarief, 1997). Produktivitas secara umum mengandung pengertian perbandingan antara hasil yang dicapai dengan keseluruhan sumberdaya yang digunakan atau secara sederhana, merupakan perbandingan antara keluaran (output) dan masukan (input) (Ravianto, 1990). Produktivitas kerja merupakan hasil yang berkesinambungan antara individu tenaga kerja dengan lingkungan di luar pekerjaan, termasuk lingkungan fisik, lingkungan sosial budaya dan lingkungan psikologi (Ravianto, 1985).

Pekerjaan yang mengandalkan fisik memerlukan kerja atau aktivitas fisik yang lebih 
berat dibanding pekerjaan yang mengandalkan keahlian FAO/WHO/UNU (2001). Khumaidi (1989) menyatakan, semakin berat aktivitas yang dilakukan, semakin banyak energi yang diperlukan untuk melakukan aktivitas tersebut. Sehingga pekerjaan yang mengandalkan kekuatan fisik akan membutuhkan energi yang lebih besar dibanding pekerjaan yang tidak mengandalkan kekuatan fisik.

Karsin (2004) menyatakan bahwa energi yang diperlukan tubuh dapat diperoleh dari pangan yang dikonsumsi. Kebutuhan energi sebaiknya diimbangi oleh asupan energi dengan jumlah yang sama. Pergizi Pangan (1999) menyatakan, kebutuhan energi yang tidak terpenuhi akan mengakibatkan manusia tidak dapat bekerja secara optimal yang pada akhirnya dapat menurunkan produktivitas.

Tiap orang memiliki aktivitas atau kegiatan di luar pekerjaan yang dilakukan setiap hari. Kegiatan wajib tersebut meliputi kegiatan domestik rumah tangga, bersosialisasi, rekreasi dan lainnya (FAO/WHO/UNU, 2001). Aktivitas fisik di luar pekerjaan yang terlalu berat serta tidak diimbangi dengan istirahat yang cukup dapat menimbulkan rasa penat. Kepenatan atau tingkat ketegangan mempengaruhi produktivitas kerja. (Ravianto, 1985) menyatakan semakin tinggi tingkat kepenatan seseorang maka produktivitas kerja semakin rendah. Berdasarkan uraian tersebut, peneliti tertarik untuk meneliti aktivitas fisik, tingkat konsumsi energi, dan produktivitas kerja khususnya kepala keluarga wanita pemetik teh.

Penelitian ini bertujuan untuk menganalisis hubungan aktivitas fisik dan tingkat konsumsi energi dengan produktivitas kerja kepala keluarga wanita pemetik teh di perkebunan teh.

\section{METODE PENELITIAN}

\section{Desain, Tempat dan Waktu Penelitian}

Penelitian ini menggunakan desain cross sectional study, semua data yang dibutuhkan dikumpulkan dalam satu waktu (Singarimbun \& Effendi, 2006). Penelitian dilakukan di kawasan perkebunan teh milik PTPN VIII di daerah Kecamatan Pangalengan, Bandung Selatan, pada cluster terpilih yaitu kebun Malabar. Penelitian dilakukan sejak Maret hingga Juni 2008.

\section{Penarikan contoh}

Kriteria contoh dalam penelitian ini adalah pria dewasa yang merupakan kepala kelu- arga dari keluarga wanita pemetik teh pada cluster terpilih (Malabar). Populasi contoh ialah keluarga wanita pemetik teh yang memiliki anak usia dini (0-72 bulan) dengan jumlah 504 keluarga yang dipilih secara acak dalam penelitian sebelumnya (Sunarti, Roosita \& Herawati, 2007). Contoh tersebar dalam lima cluster yang ada di kawasan perkebunan yaitu Purbasari $(n=96)$, Malabar $(n=102)$, Talun Santosa $(n=67)$, Sedep $(n=96)$, dan Rancabali $(n=146)$. Jumlah contoh pada cluster terpilih ialah 102 keluarga, namun lima keluarga telah pindah dari kawasan kebun Malabar sehingga contoh tersisa 97. Kriteria inklusi lainnya yaitu 1) isteri dari keluarga contoh ialah wanita pemetik teh yang masih aktif bekerja sebagai pemetik teh, 2) contoh tinggal di lokasi penelitian bersama keluarganya, dan 3) contoh masih aktif bekerja. Dari 97 contoh, 25 contoh drop out karena tidak memenuhi ketiga kriteria tersebut sehingga contoh penelitian seluruhnya berjumlah 72 orang.

\section{Pengumpulan dan pengolahan data}

Data didapatkan melalui wawancara langsung yang meliputi karakteristik contoh, recall aktivitas fisik (2x24 jam), recall konsumsi pangan (2×24 jam), dan produktivitas kerja. Data terkumpul selanjutnya dianalisis secara statistik. Tahapan pengolahan data dimulai dari verifikasi, coding, entri, cleaning, dan selanjutnya dianalisis.

Karakteristik contoh meliputi usia, pendidikan, pendapatan, dan ukuran keluarga. Usia contoh dikategorikan menjadi tiga golongan berdasarkan WNPG (2004) yaitu dewasa muda (19-29 tahun), dewasa madya (30-49 tahun), dan dewasa akhir (50-64 tahun). Pendidikan contoh dikategorikan menjadi tidak sekolah, tidak tamat SD, tamat SD, SMP/sederajat, dan SMA/sederajat. Pendapatan per kapita dikategorikan berdasarkan garis kemiskinan Kabupaten Bandung (BPS 2006), yaitu miskin (< Rp. 186,774.00) dan tidak miskin ( $\geq$ Rp. 186,774.00). Besar keluarga menurut Hurlock (1993) dikategorikan menjadi tiga, yaitu keluarga kecil ( $\leq 4$ orang), keluarga sedang (5-7 orang), dan keluarga besar ( $\geq 8$ orang).

Aktivitas fisik diukur dengan Physical Acitivity Level (PAL) dalam FAO/WHO/UNU (2001). Aktivitas fisik kemudian digolongkan menjadi 3 golongan yaitu ringan $(1.40 \leq \mathrm{PAL}$ $\leq 1.69)$, sedang $(1.70 \leq \mathrm{PAL} \leq 1.99)$, dan berat $(2.00 \leq \mathrm{PAL} \leq 2.40)$. Jenis aktivitas digolongkan berdasarkan penggolongan aktivitas dalam FAO /WHO/UNU (2001) 
Angka kebutuhan energi yang digunakan ditentukan dengan dua cara yaitu dengan menghitung angka pengeluaran energi aktual dan angka kecukupan energi populasi pria dewasa dalam WNPG (2004). Pengeluaran energi ditentukan dengan rumus sebagai berikut (FAO/WHO/UNU, 2001):

Pengeluaran Energi = tingkat aktivitas fisik $\mathrm{x}$ angka metabolisme basal

Angka metabolisme basal ditentukan dengan dua persamaan yaitu Schofield equation (1985) dalam FAO/WHO/UNU (2001) dan Oxford equation dalam WNPG (2004).

Angka kecukupan energi untuk kelompok pria dewasa usia 19-29 tahun, 30-49 tahun, dan 50-64 tahun berturut-turut dalam WNPG (2004) ialah $2515 \mathrm{kkal}, 2315 \mathrm{kkal}$, dan 2307 kkal per hari. Angka kecukupan tersebut kemudian dikoreksi dengan berat badan aktual sehat contoh sehingga didapatkan angka kecukupan energi koreksi.

Tabel 1. Persamaan dalam Menghitung Angka Metabolisme Basal (AMB)

\begin{tabular}{ccc}
\hline Variabel & $\begin{array}{c}\text { Rentang Usia } \\
\text { (tahun) }\end{array}$ & Persamaan \\
\hline Schofield & $18-30$ & $15.057(\mathrm{BB})+692.2$ \\
equation & $30-60$ & $11.472(\mathrm{BB})+873.1$ \\
\hline \multirow{2}{*}{ Oxford equation } & $19-29$ & $16.8(\mathrm{BB})+498$ \\
& $30-64$ & $16.0(\mathrm{BB})+462$ \\
\hline
\end{tabular}

Keterangan : BB: berat badan aktual $(\mathrm{kg})$

Produktivitas kerja ditentukan berdasarkan upah per bulan, jam kerja efektif, dan upah per jam. Upah per bulan dilihat dari besarnya upah yang diterima setiap bulan dari hasil bekerja. Jam kerja efektif dilihat dari lama waktu bekerja dikurangi waktu istirahat dalam satu hari. Upah per jam kerja dilihat dari besarnya upah yang diterima per jam.

Upah per bulan dikategorikan berdasarkan upah minimum regional (UMR) Kabupaten Bandung sebesar Rp. 672,000.00 (BPS, 2007). Tingkat upah per bulan digolongkan menjadi < Rp. 672,000.00 dan $\geq$ Rp. 672,000.00.

Jam kerja dikategorikan berdasarkan jam kerja efektif yaitu tujuh jam, didapatkan dari mengurangkan jam kerja standar delapan jam per hari (ACTRAV-ILO, 2005) dengan jam istirahat yang umum digunakan sebesar 1 jam. Tingkat jam kerja efektif dibagi menjadi dua yaitu $<7$ jam dan $\geq 7$ jam. Jumlah jam kerja efektif contoh dihitung dengan rumus :

Jam kerja efektif contoh $=J_{1}-J_{2}$
Keterangan:

$\mathrm{J}_{1}$ : Jumlah jam kerja contoh dalam 1 hari (jam)

$\mathrm{J}_{2}$ : Jumlah jam istirahat contoh dalam 1 hari (jam)

Upah per jam dikategorikan berdasarkan turunan dari upah minimum regional (UMR) Kabupaten Bandung menjadi UMR per jam kerja. Perhitungan dilakukan dengan asumsi jumlah hari kerja dalam satu bulan ialah 26 hari kerja efektif dengan 7 jam kerja efektif per hari sebagai berikut :

$$
\begin{gathered}
\text { UMR }_{\text {jam }}=\frac{\text { UMR/bulan }}{\text { HKE/bulan x Jam kerja efektif }} \\
\frac{\text { Rp. } 672,000.00}{26 \times 7}=\text { Rp. } 3,692.31 \\
\text { Keterangan : UMR }=\text { upah minimum regional } \\
\text { HKE }=\text { Hari kerja efektif }
\end{gathered}
$$

Tingkat upah per jam kerja dikategorikan menjadi dua yaitu < Rp. 3,692.31/jam dan $\geq$ Rp. 3,692.31/jam.

Analisis inferensia yang digunakan ialah korelasi Pearson, korelasi Spearman, dan independent sample t-test. Korelasi Pearson dan Spearman digunakan untuk menganalisis hubungan antar variabel. Penggunaan jenis korelasi yang digunakan berdasarkan skala data dan kenormalan distribusi data.

\section{HASIL DAN PEMBAHASAN}

\section{Karakteristik Sosial Ekonomi}

Sebagian besar contoh (77.8\%) termasuk dalam kategori dewasa madya. Lebih dari separuh jumlah contoh $(55.6 \%)$ menempuh pendidikan hingga tamat sekolah dasar. Hampir separuh jumlah contoh (40.3\%) bekerja sebagai pemetik teh, $16.7 \%$ menjadi petani atau buruh tani, $8.3 \%$ bekerja sebagai mandor atau juru tulis, $5.5 \%$ bekerja sebagai supir/tukang ojeg, $4.2 \%$ bekerja menjadi pedagang, dan $25 \%$ bekerja sebagai karyawan pabrik.

Lebih dari separuh jumlah contoh $(59.7 \%)$ masih berada di bawah garis kemiskinan Kabupaten Bandung. Berdasaran jenis pekerjaan (Tabel 2), 69.0\% contoh yang bekerja sebagai pemetik teh, berada di bawah garis kemiskinan, sedangkan $66.7 \%$ contoh yang bekerja sebagai mandor atau juru tulis termasuk kategori tidak miskin.

Berdasarkan jumlah anggota keluarga, lebih dari separuh contoh (58.3\%) termasuk keluarga sedang. Kontribusi pendapatan contoh terhadap pendapatan total keluarga ma- 
yoritas berada pada kisaran $44.89 \%$ hingga $68.77 \%$.

\section{Aktivitas Fisik}

Tingkat aktivitas fisik yang dilakukan dapat dilihat dari nilai Physical Activity Level (PAL). PAL dibagi menjadi 3 tingkatan yaitu ringan, sedang, dan berat tergantung besarnya nilai PAL (FAO/WHO/UNU, 2001). Tingkat aktivitas fisik contoh pada hari kerja lebih tinggi daripada aktivitas fisik contoh pada hari libur $(p<0.05)$. Tabel 3 menunjukkan bahwa pada hari kerja, jumlah contoh paling banyak tergolong dalam aktivitas tingkat sedang, sedangkan pada hari libur jumlah contoh paling banyak tergolong dalam aktivitas tingkat ringan. Hal ini disebabkan perbedaan jenis aktivitas dan lama alokasi waktu aktivitas yang dilakukan.

Tabel 2. Tingkat Pendapatan per Kapita berdasarkan jenis pekerjaan

\begin{tabular}{lcccc}
\hline \multirow{2}{*}{ Jenis pekerjaan } & \multicolumn{4}{c}{ Tingkat pendapatan per kapita } \\
\cline { 2 - 5 } & \multicolumn{2}{c}{$\begin{array}{c}\text { Miskin } \\
(\mathrm{n}=43)\end{array}$} & $\begin{array}{c}\text { Tidak miskin } \\
(\mathrm{n}=\mathbf{2 9})\end{array}$ \\
\cline { 2 - 5 } & $\mathrm{n}$ & $\%$ & $\mathrm{n}$ & $\%$ \\
\hline Petani/buruh tani & 9 & 75.0 & 3 & 25.0 \\
Pemetik teh & 20 & 69.0 & 9 & 31.0 \\
Mandor/juru tulis & 2 & 33.3 & 4 & 66.7 \\
Ojeg/supir & 2 & 50.0 & 2 & 50.0 \\
Pedagang & 3 & 100.0 & 0 & 0.0 \\
Karyawan pabrik & 7 & 38.9 & 11 & 61.1 \\
\hline
\end{tabular}

Alokasi waktu contoh untuk tidur ratarata pada hari libur dan hari kerja masingmasing sebesar 8.41 jam dan 7.8 jam. Alokasi waktu rata-rata untuk bekerja ialah sebesar 6.2 jam. Alokasi waktu rata-rata untuk kegiatan rekreasional meningkat pada hari libur (4 jam) dibandingkan hari kerja (2.4 jam). Namun, peningkatan alokasi waktu untuk kegiatan rumahtangga juga meningkat pada hari libur (4.4 jam) dibandingkan hari kerja (1.3 jam). Hal ini menunjukkan bahwa pada hari libur, contoh mengalokasikan waktu yang tidak digunakan untuk bekerja ke kegiatan domestik rumah tangga dan kegiatan rekreasional.

Tabel 4 menunjukkan bahwa contoh dengan pekerjaan sebagai petani/buruh tani, pemetik teh, dan karyawan pabrik cenderung memiliki tingkat aktivitas yang sedang dan berat. Sedangkan contoh dengan pekerjaan sebagai mandor cenderung memiliki tingkat aktivitas ringan (83.3\%). Hal ini dikarenakan pekerjaan seperti petani/buruh tani, pemetik teh dan karyawan pabrik merupakan jenis pekerjaan yang mengandalkan kekuatan fisik dibanding pekerjaan sebagai mandor.
Tabel 3. Sebaran Contoh berdasarkan Tingkat Aktivitas Fisik pada Hari Libur dan Hari Kerja

\begin{tabular}{lcccccc}
\hline \multicolumn{1}{c}{\begin{tabular}{c} 
Tingkat \\
\multicolumn{1}{c}{ Aktivitas }
\end{tabular}} & \multicolumn{2}{c}{ Hari Libur } & \multicolumn{2}{c}{ Hari Kerja } & \multicolumn{2}{c}{ Rata-rata } \\
\cline { 2 - 7 } & $\mathbf{n}$ & $\%$ & $\mathbf{n}$ & $\%$ & $\mathbf{n}$ & $\%$ \\
\hline $\begin{array}{l}\text { Ringan } \\
(1.40-1.69)\end{array}$ & 8 & 47.1 & 15 & 22.1 & 19 & 26.4 \\
$\begin{array}{l}\text { Sedang } \\
(1.70-1.9)\end{array}$ & 3 & 17.6 & 27 & 39.7 & 29 & 40.3 \\
$\begin{array}{l}\text { Berat } \\
\text { 2.0-2.40) }\end{array}$ & 6 & 35.3 & 26 & 38.2 & 24 & 33.3 \\
$\begin{array}{l}\text { Jumlah } \\
\text { Min-maks }\end{array}$ & 17 & 100.0 & 68 & 100.0 & 72 & 100.0 \\
Rata-rata \pm sd & $1.73-2.26$ & $1.41-2.40$ & $1.41-2.40$ \\
\hline
\end{tabular}

Tabel 4. Sebaran Contoh berdasarkan Jenis Pekerjaan dan Tingkat Aktivitas

\begin{tabular}{lcccccc}
\hline \multirow{2}{*}{ Jenis pekerjaan } & \multicolumn{5}{c}{ Tingkat aktivitas } \\
\cline { 2 - 8 } & \multicolumn{2}{c}{ Ringan } & \multicolumn{3}{c}{ Sedang } & \multicolumn{2}{c}{ Berat } \\
\cline { 2 - 8 } & $\mathrm{n}$ & $\%$ & $\mathrm{n}$ & $\%$ & $\mathrm{n}$ & $\%$ \\
\hline Petani/buruh tani & 2 & 16.7 & 6 & 50.0 & 4 & 33.3 \\
Pemetik teh & 5 & 17.2 & 11 & 37.9 & 13 & 44.8 \\
Mandor/juru tulis & 5 & 83.3 & 1 & 16.7 & 0 & 0.0 \\
Ojeg/supir & 2 & 50.0 & 2 & 50.0 & 0 & 0.0 \\
Pedagang & 1 & 33.3 & 1 & 33.4 & 1 & 33.3 \\
Karyawan pabrik & 4 & 22.2 & 8 & 44.5 & 6 & 33.3
\end{tabular}

Pengeluaran energi rata-rata berdasarkan Schofield equation lebih tinggi pada hari kerja (2869 kkal) dibanding dengan hari libur (2644 kkal) $(p<0.05)$. Demikian pula berdasarkan Oxford equation, pengeluaran energi ratarata pada hari kerja (2563 kkal) cenderung lebih tinggi dibanding hari libur (2373 kal) (Tabel 5).

Pengeluaran energi berdasarkan perhitungan dengan Schofield equation dan Oxford equation merupakan besarnya energi yang dikeluarkan untuk melakukan kegiatan dalam satu hari. Dengan demikian angka pengeluaran energi tersebut ialah jumlah energi yang dibutuhkan oleh tiap individu dalam satu hari. Selain itu, digunakan pula angka kecukupan energi bagi pria dewasa yang dicantumkan dalam WNPG (2004). Angka kecukupan energi tersebut kemudian dikoreksi dengan berat badan aktual sehat contoh sehingga menjadi angka kebutuhan per individu.

Tabel 5. Rata-rata Pengeluaran Energi pada Hari Libur dan Hari Kerja berdasarkan Schofield Equation dan Oxford Equation

\begin{tabular}{lccc}
\hline \multicolumn{1}{c}{$\begin{array}{c}\text { Pengeluaran } \\
\text { energi }\end{array}$} & \multicolumn{3}{c}{ Rata-rata \pm sd } \\
\cline { 2 - 4 } & $\begin{array}{c}\text { Hari libur } \\
(\mathrm{n}=17)\end{array}$ & $\begin{array}{c}\text { Hari kerja } \\
(\mathrm{n}=68)\end{array}$ & $\begin{array}{c}\text { Rata-rata } \\
(\mathrm{n}=72)\end{array}$ \\
\hline $\begin{array}{l}\text { Schofield equation } \\
\text { (kkal/hari) }\end{array}$ & $2644 \pm 476$ & $2869 \pm 402$ & $2824 \pm 401$ \\
$\begin{array}{l}\text { Oxford equation } \\
\text { (kkal/hari) }\end{array}$ & $2373 \pm 498$ & $2563 \pm 404$ & $2525 \pm 401$ \\
\hline
\end{tabular}




\section{Konsumsi Energi}

Konsumsi energi rata-rata, kebutuhan energi rata-rata berdasarkan Schofield equation dan Oxford equation serta WNPG (2004), dan tingkat konsumsi energi rata-rata dapat dilihat pada Tabel 6. Kebutuhan energi paling besar ialah berdasarkan Schofield equation, lalu diikuti Oxford equation, dan kemudian WNPG $(2004)(p<0.05)$. Kebutuhan energi ratarata berdasarkan Schofield equation lebih tinggi sebesar rata-rata $12.3 \%$ dibanding kebutuhan energi berdasarkan Oxford equation. Hal ini membuktikan pernyataan dalam WNPG (2004) bahwa Schofield equation menghasilkan angka yang overestimate sebesar $10-15 \%$ jika digunakan untuk perhitungan kebutuhan energi ras Asia. Kebutuhan energi rata-rata berdasarkan Oxford equation lebih tinggi dibanding WNPG (2004). Hal ini diduga karena angka pengeluaran energi yang dicantumkan dalam tabel angka kecukupan energi dalam WNPG (2004) berdasarkan asumsi tingkat aktivitas rata-rata populasi pria dewasa sebesar 1.69 yang tergolong dalam kategori sedang.

Tabel 6. Rata-rata Konsumsi, Kebutuhan, dan Tingkat Konsumsi Energi berdasarkan Kelompok Usia

\begin{tabular}{|c|c|c|c|}
\hline \multirow[b]{2}{*}{ Variabel } & \multicolumn{3}{|c|}{ Rata-rata \pm sd } \\
\hline & $\begin{array}{c}\text { Dewasa } \\
\text { muda } \\
(n=10)\end{array}$ & $\begin{array}{c}\text { Dewasa } \\
\text { madya } \\
(n=56)\end{array}$ & $\begin{array}{c}\text { Dewasa } \\
\text { akhir } \\
(\mathrm{n}=6)\end{array}$ \\
\hline $\begin{array}{l}\text { Konsumsi Energi } \\
\text { (kkal/hari) }\end{array}$ & $2855 \pm 330.0$ & $2368 \pm 804.7$ & $2348 \pm 403.6$ \\
\hline \multicolumn{4}{|l|}{$\begin{array}{l}\text { Schofield } \\
\text { equation }\end{array}$} \\
\hline $\begin{array}{l}\text { Kebutuhan energi } \\
\text { (kkal/hari) }\end{array}$ & $3007 \pm 377.0$ & $2799 \pm 414.0$ & $2760 \pm 244.1$ \\
\hline $\begin{array}{l}\text { Tingkat konsumsi } \\
\text { energi (\%) }\end{array}$ & $96.4 \pm 16.8$ & $85.5 \pm 28.4$ & $85.5 \pm 15.8$ \\
\hline \multicolumn{4}{|l|}{ Oxford equation } \\
\hline $\begin{array}{l}\text { Kebutuhan energi } \\
\text { (kkal/hari) }\end{array}$ & $2813 \pm 362.1$ & $2479 \pm 410.6$ & $2471 \pm 304.6$ \\
\hline $\begin{array}{l}\text { Tingkat konsumsi } \\
\text { energi }(\%)\end{array}$ & $103.2 \pm 18.4$ & $97.2 \pm 33.7$ & $96.4 \pm 20.6$ \\
\hline \multicolumn{4}{|l|}{ WNPG (2004) } \\
\hline $\begin{array}{l}\text { Kebutuhan energi } \\
\text { (kkal/hari) }\end{array}$ & $2316 \pm 199.3$ & $1986 \pm 223.4$ & $2084 \pm 401.4$ \\
\hline $\begin{array}{l}\text { Tingkat konsumsi } \\
\text { energi }(\%)\end{array}$ & $124.7 \pm 21.8$ & $121.1 \pm 45.1$ & $117.2 \pm 32.8$ \\
\hline
\end{tabular}

Tingkat konsumsi energi rata-rata berdasarkan angka kebutuhan energi menurut Schofield equation ialah sebesar $87.2 \%$, tingkat konsumsi energi rata-rata berdasarkan Oxford equation ialah sebesar $97.9 \%$, dan tingkat konsumsi energi rata-rata berdasarkan angka kecukupan energi WNPG (2004) ialah sebe- sar $121.2 \%$. Perbedaan tingkat konsumsi ini karena angka kebutuhan yang berbeda.

Hasil uji statistik menunjukkan bahwa konsumsi energi rata-rata pada kelompok dewasa muda lebih tinggi dibanding konsumsi energi rata-rata dewasa madya dan akhir $(p<0.05)$. Tingkat konsumsi energi rata-rata pada kelompok dewasa muda cenderung lebih tinggi dibanding dua kelompok usia lain, baik berdasarkan Schofield equation, Oxford equation dan angka kecukupan energi WNPG (2004).

\section{Produktivitas Kerja}

\section{Upah per bulan}

Menurut Ravianto (1990) upah merupakan salah satu cerminan kemampuan seseorang dalam melakukan pekerjaannya. Upah yang dirasa oleh pekerja setimpal dengan pekerjaan yang dilakukan dapat memacu peningkatan produktivitas pekerja. Upah yang memadai juga memberikan keleluasaan bagi pekerja untuk memenuhi berbagai kebutuhan hidup, terutama kebutuhan pangan yang dapat memberikan energi untuk melakukan pekerjaan dengan lebih baik.

Upah terkecil contoh per bulan ialah sebesar Rp. 75,000.00 dan upah terbesar per bulan ialah Rp. 1,200,000.00. Upah contoh ratarata ialah sebesar $\mathrm{Rp}$. 457,416.70, lebih rendah bila dibandingkan upah minimum regional (UMR) Kabupaten Bandung dan hanya 23.6\% contoh yang memiliki upah per bulan di atas upah minimum regional (UMR) Kabupaten Bandung (Tabel 7).

Tabel 7. Sebaran Contoh berdasarkan Tingkat Upah per Bulan

\begin{tabular}{ccc}
\hline Upah per bulan & \multicolumn{2}{c}{ Jumlah } \\
\cline { 2 - 3 } & $\mathbf{n}$ & $\%$ \\
\hline Di bawah UMR (<Rp. 672,000) & 55 & 76.4 \\
Di atas UMR (Rp. 672,000) & 17 & 23.6 \\
\hline Jumlah & 72 & 100.0 \\
\hline Min-maks & Rp. 75,000 - 1,200,000 \\
\hline Rata-rata \pm sd & $457,416.7 \pm 229,832.1$ \\
\hline
\end{tabular}

Tabel 8 menunjukkan bahwa seluruh contoh yang bekerja sebagai petani/buruh tani, tukang ojeg/supir, dan pedagang memiliki upah per bulan di bawah Rp. 672,000.00. Sebagian besar contoh yang bekerja sebagai mandor/juru tulis memiliki besar upah di atas Rp. 672,000.00. Keadaan ini berbalik dengan jumlah tenaga yang dikeluarkan. Petani/buruh tani dan pemetik teh merupakan jenis peker- 
jaan yang cenderung mengeluarkan banyak tenaga, namun upah yang diterima cenderung di bawah upah minimum regional dan hidup dalam kesejahteraan yang minim.

\section{Jam kerja}

Menurut Sastrowinoto (1985), peningkatan jumlah jam kerja tidak selalu meningkatkan produktivitas seorang pekerja. Waktu bekerja yang melebihi waktu standar cenderung menurunkan produktivitas, pekerja cenderung merasa penat dan tegang, sehingga cenderung untuk melakukan kegiatan istirahat lebih banyak. Hal ini menyebabkan waktu tersebut tidak digunakan secara efektif dalam melakukan pekerjaan.

Tabel 8. Sebaran Contoh berdasarkan Jenis Pekerjaan dan Tingkat Upah per Bulan

\begin{tabular}{lcccc}
\hline \multirow{3}{*}{ Jenis pekerjaan } & \multicolumn{4}{c}{ Tingkat upah per bulan } \\
\cline { 2 - 5 } & \multicolumn{1}{c}{ Rp. 672,000.00 } & $\mathbf{2}$ Rp. $\mathbf{6 7 2 , 0 0 0 . 0 0}$ \\
\cline { 2 - 5 } & $\mathrm{n}$ & $\%$ & $\mathrm{n}$ & $\%$ \\
\hline Petani/buruh tani & 12 & 100.0 & 0 & 0.0 \\
Pemetik teh & 24 & 82.8 & 5 & 17.2 \\
Mandor/juru tulis & 1 & 16.7 & 5 & 83.3 \\
Ojeg/supir & 4 & 100.0 & 0 & 0.0 \\
Pedagang & 3 & 100.0 & 0 & 0.0 \\
Karyawan pabrik & 11 & 61.1 & 7 & 38.9 \\
\hline
\end{tabular}

Jam kerja contoh tersingkat ialah tiga jam dan jam kerja terpanjang ialah 12 jam, dengan jam kerja contoh rata-rata ialah 6.2 jam. Tabel 9 menunjukkan bahwa $62.5 \%$ contoh masih bekerja di bawah jam efektif. Lama jam istirahat contoh terpanjang ialah sebesar 5 jam dengan nilai rata-rata 1.3 jam.

Tabel 9. Sebaran Contoh berdasarkan Jam Kerja

\begin{tabular}{ccc}
\hline \multirow{2}{*}{ Jam kerja } & \multicolumn{2}{c}{ Jumlah } \\
\cline { 2 - 3 } & $\mathrm{n}$ & 62.5 \\
\hline$<7$ jam & 45 & 37.5 \\
$\geq 7$ jam & 27 & 100.0 \\
\hline Jumlah & 72 & \multicolumn{2}{c}{$3.0-12.0$ jam } \\
\hline Min-maks & \multicolumn{2}{c}{$6.8 \pm 1.6$} \\
\hline Rata-rata \pm sd
\end{tabular}

\section{Upah per jam}

Upah per jam merupakan besarnya upah yang diterima per jam kerja yang dilakukan. Upah per jam contoh yang paling kecil ialah Rp. 461.54 dan upah per jam contoh yang paling besar ialah Rp. 5,917.16, dengan upah per jam rata-rata ialah Rp. 2,652.55. Tabel 10 menunjukkan bahwa $73.6 \%$ contoh memiliki upah per jam di bawah Rp. 3,692.31.
Tabel 10. Sebaran Contoh berdasarkan Tingkat Upah per Jam Kerja

\begin{tabular}{ccc}
\hline \multirow{2}{*}{ Tingkat upah per jam } & \multicolumn{2}{c}{ Jumlah } \\
\cline { 2 - 3 } & $\mathrm{n}$ & $\%$ \\
\hline Upah per jam < Rp. 3,692.31 & 53 & 73.6 \\
Upah per jam $\geq$ Rp. 3,692.31 & 19 & 26.4 \\
\hline Jumlah & 72 & 100.0 \\
\hline Min-maks & $461.5-5917.2$ \\
\hline Rata-rata \pm sd & $2,652.6-1,408.0$ \\
\hline
\end{tabular}

Faktor-faktor yang Berhubungan dengan Tingkat Aktivitas Fisik dan Produktivitas Kerja

Hasil uji korelasi menunjukkan bahwa semakin rendah tingkat pendidikan, maka tingkat aktivitas akan semakin berat $(r=-0.267$, $\mathrm{p}<0.05)$. Selain itu, tingkat aktivitas yang semakin ringan berhubungan dengan jam kerja yang semakin lama $(r=-0.251, p<0.05)$. Hal ini menunjukkan bahwa jenis pekerjaan dengan tingkat aktivitas yang ringan cenderung memiliki durasi yang lebih panjang. Sebaliknya, jenis pekerjaan dengan tingkat aktivitas yang berat cenderung memiliki durasi yang singkat.

Pada kelompok usia produktif bertambahnya usia seseorang, berkorelasi dengan semakin besar upah per bulan $(r=0.398, p<0.01)$ dan upah per jam $(r=0.260, p<0.05)$. Hal ini menunjukkan bahwa dengan semakin meningkatnya usia dalam rentang usia produktif, maka kemampuan contoh dalam mendapatkan upah semakin meningkat. Menurut Santrock (2002), sejak fase dewasa muda kemampuan, baik secara fisik maupun psikologis (motivasi, obsesi, dan lain sebagainya), akan terus berkembang dan menjadi stabil saat memasuki fase dewasa madya.

Hasil uji korelasi juga menunjukkan bahwa dengan semakin bertambahnya usia, maka jam kerja semakin panjang $(r=0.308, p<0.01)$. Bee (1987) menyatakan bahwa penambahan usia menyebabkan seseorang mampu melakukan suatu jenis pekerjaan tertentu dengan durasi yang lebih panjang. Selain itu Keitner dan Kinicki (2005) menyatakan bahwa jika kebutuhan dasar dirasa telah terpenuhi maka kebutuhan lain yang lebih tinggi akan segera muncul. Hal ini diduga menjadi salah satu faktor yang berkaitan dengan lamanya jam kerja. Meningkatnya motivasi untuk mengaktualisasikan diri menyebabkan semakin singkatnya istirahat yang dilakukan di luar waktu istirahat, sehingga jam kerja yang dijalani lebih panjang.

Semakin besar upah per bulan $(r=0.780$, $p<0.01)$ dan upah per jam kerja $(r=0.453$, $\mathrm{p}<0.01)$ maka pendapatan per kapita yang di- 
dapatkan juga lebih besar. Hubungan ini dapat bersifat timbal balik. Peningkatan upah yang diterima kepala keluarga mampu meningkatkan pendapatan keluarga. Selanjutnya, peningkatan pendapatan keluarga merupakan motivasi kepala keluarga untuk bekerja lebih giat dan mendapatkan hasil yang lebih baik.

Semakin banyak jumlah anggota keluarga, maka upah per bulan yang diterima akan semakin besar $(r=0.241, p<0.05)$. Hal ini sejalan dengan hasil penelitian Puspitarini (2005) yang menunjukkan bahwa jumlah tanggungan keluarga berpengaruh nyata terhadap produktivitas kerja buruh olah di kebun Rancabali PTPN VIII. Setiap penambahan satu orang anggota keluarga, produktivitas kerja buruh olah akan meningkat sebesar 1.6896 kg/HKE.

Ravianto (1985) dan Kreitner dan Kinicki (2005) menyatakan bahwa motivasi merupakan kondisi mental yang memberikan energi untuk memenuhi kebutuhan atau memberi kepuasan dan akan terus mendorong hingga kebutuhan terpenuhi atau kepuasan tercapai.

\section{KESIMPULAN}

Hampir separuh jumlah contoh melakukan aktivitas fisik dalam kategori sedang (PAL rata-rata $=1.89$ ). Tingkat aktivitas contoh lebih tinggi pada hari kerja $(p<0.05)$. Pada hari libur, contoh mengalokasikan waktu yang tidak digunakan untuk bekerja ke kegiatan domestik rumah tangga dan kegiatan rekreasional. Faktor yang berhubungan dengan aktivitas ialah pendidikan, semakin tinggi pendidikan maka semakin ringan tingkat aktivitasnya.

Pengeluaran energi contoh berdasarkan Schofield equation tertinggi pada hari kerja yaitu rata-rata sebesar 2869 kkal $(p<0.05)$. Berdasarkan Oxford equation, pengeluaran energi contoh tertinggi pada hari kerja yaitu rata-rata sebesar 2563 kkal. Rata-rata kebutuhan energi paling tinggi berdasarkan Schofield equation, diikuti Oxford equation, dan paling rendah berdasarkan WNPG (2004) $(p<0.05)$. Rata-rata tingkat konsumsi energi pada hari kerja berdasarkan Schofield equation, Oxford equation, dan WNPG (2004) masing-masing $87.2 \%$, 97.9\%, dan $121.2 \%$. Tingkat konsumsi energi rata-rata pada kelompok dewasa muda cenderung lebih tinggi dibanding dua kelompok usia lain, baik berdasarkan Schofield equation, Oxford equation dan angka kecukupan energi WNPG (2004).

Berdasarkan upah per bulan, lebih dari separuh jumlah contoh memiliki upah per bu- lan di bawah UMR Kabupaten Bandung. Berdasarkan jumlah jam kerja efektif lebih dari separuh jumlah contoh memiliki jam kerja di bawah jam kerja efektif dan berdasarkan upah per jam, lebih dari separuh jumlah contoh memiliki upah per jam kurang dari standar upah per jam. Berdasarkan ketiga aspek tersebut, dapat dikatakan bahwa produktivitas kerja suami pemetik teh masih rendah.

Faktor-faktor yang berhubungan secara signifikan dengan upah per bulan ialah usia, pendapatan perkapita, dan besar keluarga. Faktor-faktor yang berhubungan secara signifikan dengan jam kerja ialah usia dan tingkat aktivitas. Faktor-faktor yang berhubungan secara signifikan dengan produktivitas kerja dengan indikator upah per jam ialah usia dan pendapatan perkapita.

\section{UCAPAN TERIMA KASIH}

Terima kasih disampaikan kepada Dr. Euis Sunarti selaku ketua tim peneliti proyek riset yang didanai oleh neys van hoogstraten Foundation (NHF) atas bantuan informasi dan dana publikasi. Bapak Ir. Nandi Suhandi beserta staf PTPN VIII Unit Perkebunan Malabar yang telah memberikan izin tempat untuk melakukan penelitian serta kerja sama yang baik, keluarga Bapak Suhendar atas keramahan yang diberikan, Pemerintahan serta warga Desa Banjarsari Kecamatan Pangalengan atas bantuan yang diberikan, serta teman-teman peneliti atas kerja sama yang baik selama pengambilan data di Pengalengan, dan seluruh pihak yang telah membantu dan mendukung pelaksanaan penelitian ini.

\section{DAFTAR PUSTAKA}

[ACTRAV - ILO]. 2005. Human Rights at Work. [newsletter] Volume 3 no 05. http:// www.ilo.org.html [Maret 2008].

Akmal Y. 2006. Analisis Faktor-faktor yang Mempengaruhi Produktivitas Tenaga Kerja Industri Kecil Kerupuk Sanjai di Kota Bukittinggi. Skripsi Sarjana Program Studi Ekonomi Pertanian dan Sumberdaya. Fakultas Pertanian. IPB, Bogor.

Bee HL. 1987. The Journey of Adulthood. MC Millan Publishing, USA 
[BPS] Badan Pusat Statistik. 2006. Data dan Informasi Kemiskinan Tahun 2005-2006 Buku 2: Kabupaten. BPS, Jakarta

FAO/WHO/UNU. 2001. Human Energy Requirement, Report of a Joint $\mathrm{FAO} / \mathrm{WHO} / \mathrm{UNU}$ Expert Consultation. 17-24 October, Rome.

Hurlock. 1993. Perkembangan Anak. Erlangga, Jakarta.

Istiadah MA. 1999. Pembagian Kerja Rumah Tangga dalam Islam. Asia Foundation, Jakarta

Karsin ES. 2004. Klasifikasi Pangan dan Gizi. Dalam Baliwati YF, Khomsan A, Dwiriani CM (Eds.), Pengantar Pangan dan Gizi. Panebar Swadaya, Jakarta

Khumaidi M. 1989. Gizi Masyarakat. Departemen Pendidikan dan Kebudayaan, Direktorat Jenderal Pendidikan Tinggi, Pusat antar Universitas Pangan dan Gizi IPB, Bogor

Kreitner R, Kinicki A. 2005. Perilaku Organisasi. Ed ke-5. (Erly Suandy, penerjemah). Salemba Empat, Jakarta. Terjemahan dari: Organizational Behavior. Ed ke-5.

[Pergizi Pangan] Perhimpunan Peminat Gizi dan Pangan. 1999. Pembangunan Gizi dan Pangan dari Perspektif Kemandirian lokal. Thaha R, Hardinsyah, Ala A (Eds.), Pergizi Pangan, Jakarta.
Puspitarini M. 2005. Analisis Produktivtas Kerja Buruh Olah di PT. Perkebunan Nusantara VIII Kebun Rancabali Kecamatan Rancabali Kabupaten Bandung Provinsi Jawa Barat. Skripsi Sarjana Program Ekstensi Manajemen Agribisnis, Fakultas Pertanian, IPB, Bogor.

Ravianto J. 1985. Produktivitas dan Manusia Indonesia. SIUP, Jakarta. . 1990. Produktivitas dan Tenaga Kerja Indonesia. SIUP, Jakarta.

Santrock JW. 2002. Life-Span Development. MC Graw Hill, USA.

Sastrowinoto S. 1985. Meningkatkan Produktivitas dengan Ergonomi. Pustaka Binaman Pressindo, Jakarta.

Singarimbun M \& Effendi S. 2006. Metode Penelitian Survei. LP3ES, Jakarta.

Sunarti E, Roosita K, Herawati T. 2007. Studi Wanita Pemetik Teh: Status Sosial Ekonomi, Ketahanan Keluarga, Konsumsi Pangan, serta Pertumbuhan dan Perkembangan Anak [laporan kemajuan].

Syarief H. 1997. Membangun Sumberdaya Manusia Berkualitas Orasi Ilmiah Guzu Besar Ilmu Gizi Masyarakat dan Sumberdaya Keluarga, Fakultas Pertanian, IPB, Bogor.

[WNPG] Widyakarya Nasional Pangan Gizi. 2004. Ketahanan Pangan dan Gizi di Era Otonomi Daerah dan Globalisasi. LIPI, Jakarta. 